\title{
Marx: considerações sobre o seu legado
}

\author{
Marx: considerations on his legacy
}

\section{José Fernando Siqueira da SILVA*}

Resumo: O artigo em questão trata do legado marxiano como teoria social crítica ao capital e à sociedade que permite sua reprodução ampliada: o capitalismo. Destaca a importância da categoria "totalidade" na produção teórico-prática do autor. Refuta, portanto, análises dogmáticas, logicistas, economicistas ou academicistas sobre a obra de Marx, sobre seu significado sócio-histórico e sobre sua atualidade.

Palavras-chave: Marx. Teoria Social. Totalidade.

Abstract: This article deals with the Marxist legacy as being a social theory critical of capital and of the society which permits its amplified reproduction: capitalism. It emphasises the importance of the category of "totality" in Marx's works. It refutes, therefore, the dogmatic, logical, economic or academic analyses of Marx's works, of its social-historical meaning and current importance.

Key words: Marx. Social theory. Totality.

Submetido em: 29/4/2018. Aceito em: 24/7/2018.

[...] toda ciência seria supérflua se a forma de manifestação e a essência das coisas coincidissem imediatamente. [...] (MARX, 1985, v. III/2, p. 71).

\section{OBSERVAÇÕES INTRODUTÓRIAS}

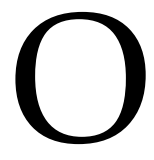

tema proposto para este volume da Revista Argumentum, 135 anos sem Marx: desafios para a esquerda mundial, estimula um debate de grande importância às esquerdas mundiais e latino-americanas comprometidas com níveis crescentes de emancipação humano-social: a validade do legado de Marx para reconstruir mentalmente contradições objetivamente postas na sociedade burguesa atual e estimular alternativas possíveis e capazes de tensionarem a barbárie em curso empreendida pelo capital em sua fase monopolista-financeira avançada. O que se pretende analisar aqui não é a contribuição teórica e prática de Marx, sua apropriação enciclopédica ou sua aplicação militante, mas sua inserção teórico-prática - como práxis - marcada por condições sóciohistóricas específicas que reafirmam a dialética sujeito-objeto em que homens e mulheres fazem história a partir de condições materiais determinadas. As páginas que se seguem, insuficientes para tal empreitada, se limitarão a recuperar alguns aspectos centrais que estruturam a proposta marxiana como teoria social orientada pela perspectiva de totalidade, impensável sem uma apropriação histórico-dialética do movimento do real, nada afeita a

\footnotetext{
*Assistente Social. Doutor em Serviço Social pela Pontifícia Universidade Católica de São Paulo. Livredocente em Serviço Social pela UNESP. Docente do Programa de Pós-Graduação em Serviço Social e Políticas Sociais da Universidade Federal de São Paulo (UNIFESP, São Paulo, Brasil). Rua Silva Jardim, ${ }^{\circ}$ 136, Santos (SP), CEP.: 11015-021. Professor do Departamento de Serviço Social da UNESP-Franca (graduação). Av. Eufrásia Monteiro Petráglia, $n^{\circ}$ 900, Jardim Doutor Antônio Petráglia, Franca (SP), CEP.: 14409-160. Bolsista produtividade em pesquisa do CNPq. E-mail: <jfernandotemporalis@terra.com.br>. ORC ID: <https://orcid.org/oooo-0oo3-1040-9558>.
} 
receituários ou aplicações dogmáticas. O velho Marx, essencial embora insuficiente (e ele próprio assim entendeu sua contribuição), teima em resistir a diversas mortes anunciadas de seu legado, como uma afirmação logicista burguesa que impõe à realidade uma lógica que não é dela. A miséria da razão burguesa, sem qualquer base real, realiza exatamente seu oposto: reafirma as tensões internas e a incapacidade de a sociedade do capital solucioná-las no limite de suas fronteiras; em outras palavras, reafirma a atualidade de Marx.

\section{ELEMENTOS FUNDANTES DA TEORIA SOCIAL DE MARX}

A teoria social de Marx não é composta por um receituário científico forjado na mente genial de estudiosos. Não se trata, portanto, em hipótese alguma, de uma "[...] coisa da lógica [...]" (MARX, 2005a, p. 39), como um conjunto de ideias que fundam o real e o comandam logicamente, aproximando e identificando pensamento e realidade e substituindo a gênese do real pela dedução lógica, como o fez Hegel, ainda que dialeticamente (LUKÁCS, 2010 e 2012)․․ A obra marxiana é reconstrução mental do materialmente posto, como "lógica da coisa", como concreto que se pensa. Todavia, esse concreto, sua dinâmica objetivamente posta, não se revela espontaneamente, não brota naturalmente e sensivelmente para ser contemplado na sua imediaticidade como assim pensou Feuerbach (MARX; ENGELS, 2007). Marx rebate, assim, concepções materialistas que se conformam com o imediatamente posto - diretamente captável por meio dos sentidos - tendência esta que elimina a ação prático-crítica de seres sociais como sujeitos históricos possíveis, ativos (ainda que relativamente) ${ }^{2}$. Em outras palavras, o real não se revela imediatamente. Carece, desta forma, de certo tipo de razão que se debruce sobre a realidade, sobre sua lógica e dinâmica, e a "espelhe" no pensamento. Este, por sua vez, nestas condições, não gira em si mesmo; ao contrário, persegue um movimento materialmente posto e dele se nutre como "[...] concreto-pensado [...]" (MARX, 1989, p. 410). Por isso, o conhecimento orientado pela ontologia do ser social (em termos lukásianos) historicamente determinado, com sua existência real-concreta, reconhece um movimento material situado para além das mentes pensantes, da abstração filosófica orientada pela subjetividade do ser ou por um conjunto de regras cientificamente manipuladas pelo rigor do investigador, uma vez que persegue o movimento do real, a racionalidade nela contida. Há, por isso, uma clara distinção entre a dimensão ontológica (contida na própria realidade) e a dimensão gnosiológica (de produção de conhecimentos acerca dessa realidade), destacando, aqui, a diferença entre a dinâmica do real e as representações elaboradas sobre ela. Destaca Marx (1989):

[...] a totalidade concreta, como totalidade de pensamento, como uma concreção de pensamento, é, na realidade, um produto do pensar, do conceber; não é de nenhum modo o produto do conceito que se engendra a si mesmo [...]. O todo, tal como aparece na cabeça, como um todo de pensamento, é um produto da cabeça pensante, que se apropria do mundo da única maneira em que o pode fazer, maneira

\footnotetext{
${ }^{1}$ Hegel reconhece a existência material da realidade distintamente da razão pensante e a possibilidade de conhecer sua lógica. Neste aspecto avança substancialmente em relação a Kant para quem a razão é sempre subjetiva. O faz, todavia, orientado pelo idealismo objetivo e por seu espírito absoluto dialético. Aqui reside a crítica fundamental feita por Marx a Hegel que vai muito além das observações sensitivas e contemplativas de Feuerbach.

${ }^{2}$ Marx tratou disto em As teses sobre Feuerbach, redigidas em 1844-1845 em pouco mais de duas páginas geniais.
}

Argum., Vitória, v. 10, n. 2, p. 56-69, maio/ago. 2018. 
que difere do modo artístico, religioso e prático-espiritual de se apropriar dele. $\mathrm{O}$ objeto real [realeSubjekt] permanece em pé antes e depois, em sua independência e fora da cabeça ao mesmo tempo, isto é, a cabeça não se comporta senão especulativamente, teoricamente [...] (MARX, 1989, p. 410-411).

As observações tecidas por Marx sobre seu método de estudo como componente da práxis social, na relação teoria-prática, foram se formando coerentemente com sua proposta investigativa: pesquisa rigorosa colada no movimento do real, alimentada pela militância efetiva junto ao movimento operário, fomentadora de alternativas transformadoras da realidade. Marx era, simultaneamente, intelectual e militante, um intelectual orgânico por excelência (em termos gramscianos), altamente potente, criativo, capaz de reconstruir mentalmente a dinâmica do real, tensionar as condições objetivamente dadas, estimular a crítica radical (sem sectarismos) e propor ações revolucionárias possíveis, negando o imobilismo contemplativo e o obreirismo idealista militante. Era um pensador-militante capaz de organizar criticamente o ponto de vista do trabalho, daqueles que viviam da venda da força de trabalho naquele momento histórico.

Isso exige, ainda que sumariamente, perquirir a natureza de uma importante categoria marxiana: a totalidade 3 . A realidade é rica em determinações, é saturada por múltiplas mediações que decodificam complexos sociais materialmente existentes (classes sociais, trabalho, pauperismo, entre outros). Ela sempre se expressa imediatamente, como complexo aparentemente simples, que elimina - em sua forma imediata - o processo que a explica e a constitui (o seu mediato). Revela-se, aqui, um componente insuprimível da totalidade: a singularidade, a forma inicial de aparição de relações complexas. O fetiche da mercadoria e o processo de estranhamento social analisado por Marx mais detidamente em $O$ Capital se sustentam exatamente nisso: a forma final do processo aparentemente elimina sua gênese como chave explicativa necessária para decodificar a complexidade do processo como totalidade social ${ }^{4}$. A singularidade da vida social não é uma mentira, uma deturpação ou algo que deve ser descartado. Ao contrário, trata-se apenas da forma primeira de aparição de processos complexos, componente da totalidade, embora insuficiente por si mesma. Portanto, perquirir sua trama é procedimento necessário, bem como é importante o seu caminho de volta que explica e revela os processos contidos na sua forma de aparição.

Mas essa singularidade, aparentemente reveladora de si, objeto da crítica dialética-material, expressa relações universais, socialmente explicadas, historicamente postas e determinadas por uma ordem social específica, seu metabolismo, ou seja, a forma como os homens e mulheres se organizam para produzir e reproduzir a vida, satisfazer suas carências e necessidade humanas tendo o trabalho (concreto) como categoria fundante, primeira, deste processo. Essa universalidade, para que não se perca em generalizações logicistas, precisa ser apanhada em suas particularidades, isto é, só se materializa por meio de complexos sociais que não se objetivam identicamente em todas as realidades. Ou seja, a universalidade da ordem social e suas determinações, base material que sustenta a organização da vida, se realizam nas diversas localidades por meio de mediações, conexões explicativas

\footnotetext{
3 “[...] as categorias [...] exprimem formas de vida, determinações de existência [...]" (MARX, 1989, p. 415).

4 Isso igualmente aparece, por exemplo, na forma D-D', no processo de financeirização que parece indicar a valorização do dinheiro a partir dele mesmo. Na verdade, parte da mais-valia extraída dos trabalhadores e destinada à remuneração do capital portador de juros (MARX, 1984c, 1985).
}

Argum., Vitória, v. 10, n. 2, p. 56-69, maio/ago. 2018. 
objetivamente dadas, materialmente postas, que permitem clarear como as relações universais são vividas em dada realidade. Portanto, a particularidade é o reino das mediações. A perspectiva de totalidade não se confunde com a noção de todo articulado, sistemicamente articulado, simplificado pela comunicação de partes estanques, muito menos se reduz a uma visão genérica que dissolve as partes do todo. A totalidade exige a unidade de dimensões diferentes, impensáveis e inexplicáveis sem o imediatamente aparente e o processo genético que o explica. $\mathrm{O}$ singular é rico em determinações embora não revele imediatamente sua complexidade. Os indivíduos, seres sociais potencialmente humano-genéricos, são produtos sociais que trazem na sua constituição a construção histórico-humana. Essa é a trama que forma a totalidade como categoria materialintelectual, que une, sem identificar, a singularidade, a universalidade e a particularidade. Ao contrário de Hegel que trata o contraditório como categoria puramente lógica, Marx a explica como força motriz de todo processo material, parte constituinte das lutas reais, da luta de classes (LUKÁCS, 2012).

Sendo assim, ainda que o ponto de partida seja a própria realidade, seguramente mediada pelas condições objetivas de existência, a razão tem o papel fundamental de pôr em movimento a reconstrução mental do materialmente posto, tensionar sua dureza, sua imediaticidade inata, sem o qual seria impossível desvelá-lo. A razão, portanto, para Marx, não pode permanecer dando voltas no cérebro ilustre do filósofo e dos acadêmicos munidos da varinha mágica do conhecimento. Ela não funda ao real, não possui a potência para criar a realidade. $\mathrm{O}$ que se defende, aqui, não é a eliminação da razão ou sua redução, sua desvalorização, mas a unidade-diversa entre pensar e fazer, entre a razão crítica e o imediatamente posto. A teoria, então, possui o papel de iluminar o processo, auxiliar o desvelamento da realidade. $\mathrm{O}$ método não se reduz a esquemas explicativos compostos por um conjunto de técnicas, mas se objetiva como um caminho que orienta as bases para que a razão conheça o real e seu movimento e produza teoria sobre ele. Todo esse processo está metido na trama histórica, imerso em dada historicidade, nas lutas objetivamente dadas, mediadas por interesses de classe, base material por onde individualidades tomam decisões, elaboram alternativas, exercem seu papel como sujeito histórico possível, marcado pela ordem do capital e tecida pela luta de classes. O que se objetiva, aqui, é outra relação entre teoria, método e história, muito distante de esquemas lógico-formais que impõem ao real uma dinâmica que o camufla ao invés de revelá-lo. Sendo assim, é importante ressaltar: teoria não é construção, mas reconstrução, expressão teórica do movimento do real (sempre relativa), empenhada em perquirir sua dinâmica interna, recolhendo as categorias contidas na trama desse real. Em resumo,

Marx, parte, ao contrário, da totalidade do ser na investigação das próprias conexões, e busca apreendê-las em todas as suas intrincadas e múltiplas relações, no grau máximo de aproximação possível. A totalidade não é, nesse caso, um fato formal do pensamento, mas constitui a reprodução ideal do realmente existente; as categorias não são elementos de uma arquitetura hierárquica e sistemática, mas, ao contrário, são na realidade 'formas de ser, determinações de existência', elementos estruturais de complexos relativamente totais, reais, dinâmicos, cujas inter-relações dinâmicas dão lugar a complexos cada vez mais abrangentes, em sentido tanto extensivo quanto intensivo (LUKÁCS, 2012, p. 297).

Argum., Vitória, v. 10, n. 2, p. 56-69, maio/ago. 2018. 
Mas isso não é suficiente para explicar a densidade da teoria social de Marx. O problema está em destacar desta referência o seu método (como se isso fosse possível), ainda que ele seja a única característica ortodoxa na obra marxiana conforme indicou Lukács ${ }^{5}$. O ponto de vista da totalidade exige que o método seja apropriado com base em outros aspectos inseparáveis: a crítica à teoria valor-trabalho e a perspectiva de ruptura com a ordem burguesa em curso (a revolução como possibilidade histórica concreta), preservando, claro, a necessidade de apanhá-las na historicidade, nas condições propiciadas pelo momento histórico presente (o que remete à ortodoxia do método na teoria social e evita dogmatismos). Sem isso a teoria social de Marx se perde por completo. Cabe destacar, sumariamente, a necessidade de considerar essas duas dimensões sem as quais a economia política burguesa não poderia ser desvelada e radicalmente questionada a partir de suas contradições internas ontologicamente dadas e insuperáveis dentro das fronteiras do capital, de sua sociedade (o capitalismo) e de suas características afinadas com a propriedade privada da produção social. Isso, ainda, impede procedimentos que tentam "metodoligizar" o método em Marx, ou seja, cultuar sua aplicação.

É importante reconstruir permanentemente essa tradição teórica saturando-a com as ricas determinações repostas ao longo dos últimos 150 anos, expressas no movimento histórico marcado por um processo de luta de classes em tempos de capitalismo plenamente maduro e por suas particularidades objetivadas nas diferentes regiões do globo. Isso impõe, por exemplo, à América Latina, a necessidade de conhecer-se profundamente, explicar sua diversa dinâmica, construir suas resistências, explicitar suas identidades, não como ilhas isoladas, mas como parte de uma riqueza e de um processo mundial. Reside aqui um grande equívoco que merece destaque: a oposição entre latino-americanismo e euro-centrismo, como se a América Latina falasse por si ou, ao contrário, as produções não latinas, euro-clássicas, pudessem ser aplicadas a outras regiões do globo desprezando processos mais localizados. Trata-se de procedimento básico, essencial, para perseguir o movimento do real, sempre relativamente, jamais exatamente.

Lukács, inspirado em Marx, destaca a importância de explicar as sociedades e seus indivíduos tendo por base os processos históricos e os complexos sociais que os constituem, considerando o modo como se desenvolvem, se produzem e reproduzem, ou seja, se organizam economicamente. Isso não significa recair no economicismo que submete mecanicamente toda infraestrutura ideológica à base econômica. Localiza-se, aqui, por diferentes caminhos adotados por diferentes tendências, um dos maiores equívocos cometidos contra Marx e sua teoria social: a redução dela a uma economia estrita, ao economicismo, como uma infraestrutura que determina mecanicamente a vida social. Isso gerou interpretações equivocadas que transitam por diferentes espectros ideológicos:

a) por um lado, a revolução passa a ser um desdobramento direto de certo tipo de economia centralizada e organizada por um estado, generalizada mundialmente como paradigma (também de base stalinista) ${ }^{6}$. Ou ainda, os Estados são vistos em si mesmos, como instâncias

\footnotetext{
5 “O marxismo ortodoxo não significa, pois, adesão acrítica aos resultados da pesquisa de Marx, nem 'fé' numa ou noutra tese marxiana ou a exegese de um texto 'sagrado'. A ortodoxia, em matéria de marxismo, refere-se, ao contrário e exclusivamente, ao método [...]” (LUKÁCS, 1981, p. 60).

$6 \mathrm{O}$ que não significa desconhecer a importância da história da ex-União Soviética, bem como o papel estratégico dos Estados nos processos revolucionários.
}

Argum., Vitória, v. 10, n. 2, p. 56-69, maio/ago. 2018. 
capazes de administrarem a luta de classes, conciliá-la, na direção de outra sociedade não claramente qualificada ou idealisticamente tratada como sendo a revolução possível e real. É preciso destacar que a economia em Marx tem um sentido muito mais amplo, isto é, de produção e reprodução da vida humana em geral, como base material que sustenta a satisfação de carências e necessidades, portanto momento predominante - sim - de uma totalidade de relações que, todavia, não pode ser apreendido como causa-efeito, domínio absoluto, mecânico, da economia sobre a superestrutura ideológica (LUKÁCS, 2012, 2013). Os Estados são vistos por Marx como instâncias determinadas socialmente, ainda que devam ser disputados como espaços estratégicos (MARX, 2005a). Não possuem, por isso, em si mesmos, as condições mágicas para administrar tensões de ordem estrutural. Isso não retira o valor dos Estados, quando ocupados por projetos que também representam os de baixo, ou em processo de maior radicalização revolucionária. Apenas destaca a limitação desta instância;

b) nesse mesmo sentido, mas como intencionalidade oposta, as orientações liberais/burguesas comprometidas com a redução de Marx e de sua teoria social à economia estrita, especializada, econômica (o Marx economista), obviamente despida de dialética e de qualquer espécie de orientação revolucionária;

Destaca Lukács:

Um dos motivos principais da vulgarização do marxismo, que tanto colaborou para que ele perdesse sua influência como teoria universal do desenvolvimento da humanidade, foi exatamente a concepção mecanicista de toda ideologia como mero 'produto naturalmente necessário' das respectivas relações econômicas (LUKÁCS, 2010, p. 113).

Há, todavia, um terceiro aspecto a ser destacado como parte deste empobrecimento: a tendência que retira o método em Marx do conjunto de sua obra, adotando-o como aplicação para compreender e transformar a realidade, instrumentalizar profissões, como parte da teoria do conhecimento. A crítica à teoria valor-trabalho e a perspectiva da revolução aparecem como adendos, no limite complementos de menor importância, ou mesmo são simplesmente desconsideradas.

Todas estas orientações reducionistas reproduzem um ponto fundamental: a absoluta destruição da categoria da totalidade promovendo uma parcialização grosseira que destrói a essência histórica, dialética e revolucionária da teoria social de Marx, ainda que se deva assumir que todos seus pressupostos, elaborados sob as condições do capitalismo industrial inglês, possam e devam ser revistos, adensados ou mesmo criticados e superados. Mas essa é uma necessidade imposta pela dinâmica do real que pode ser capturada pela ortodoxia do método que não coloca em xeque a exploração capitalista e a possibilidade histórica de sua superação. O que o método dialético em Marx exige é o esclarecimento objetivo, preciso, da exploração sobre as bases do capitalismo monopolista-financeiro, sua face dependente na América Latina (MARINI, 2008; FERNANDES, 2009), suas atuais determinações históricas que impactam as condições materiais reais para a revolução. Isso Marx não fez e não poderia fazê-lo jamais, embora tenha dado pistas geniais nesta direção7.

7 O livro III de "O Capital" é revelador, ponto essencial - embora insuficiente - para pensar a era monopolistaimperialista do capital (LENIN, 2008), sua financeirização crescente.

Argum., Vitória, v. 10, n. 2, p. 56-69, maio/ago. 2018. 
O vínculo estrutural do método em Marx com a crítica à teoria valor-trabalho e a perspectiva da revolução (sempre como possibilidade histórica materialmente posta a partir de condições históricas bem definidas), possui o exato sentido de explicar a produção e a reprodução do ser, tendo o trabalho como categoria fundante de sua sociabilidade, como práxis primeira, como categoria que permite aos seres humanos-sociais diminuírem paulatinamente as barreiras naturais, humanizarem a natureza ao mesmo tempo em que são transformados por ela e pela relação estabelecida com os outros seres sociais. Tal mudança ocorre por meio da própria força humana, sem eliminar sua base natural, tendo o trabalho (útil-concreto) como ponto central para a recriação do ser e de suas relações humanonaturais. Essa tendência existiu muito antes da era do capital, desde o momento em que homens e mulheres passaram a dominar conscientemente, intencionalmente, diferentes técnicas, como trabalho criativo, útil, sempre considerando como ponto de partida sua existência concreta. O domínio da técnica da produção do fogo e do uso da agricultura, por exemplo, representam saltos ontológicos imensos que alteraram radicalmente a relação da espécie humana com a natureza, consigo própria e com as outras espécies. Por isso, “[...] a essência do trabalho humano consiste no fato de que, em primeiro lugar, ele nasce em meio à luta pela existência e, em segundo lugar, todos os seus estágios são produto de sua autoatividade" (LUKÁCS, 2013, p. 43).

O trabalho, como categoria fundante na relação orgânica Homem-Natureza, certamente influenciada por momentos de incerteza, casualidades, foi absolutamente central para a sobrevivência e para a evolução da espécie humana e continua sendo fundamental para a diminuição das barreiras naturais nos dias de hoje (sem eliminá-las completamente) ${ }^{8}$. A teoria social de Marx não separa natureza e ser social, ainda que não os identifique. É exatamente o trabalho que permite a relação orgânica Homem-Natureza como prévia ideação consciente e anteriormente projetada-planejada no cérebro humano (como causalidade-finalidade), como trabalho universal que permite os sucessivos saltos ontológicos que reduzem as barreiras naturais sem jamais eliminá-las totalmente, tendo como ponto de partida suas próprias condições de existência (e isso é importante). Portanto, os homens e as mulheres constituem a natureza, fazem parte dela, mas ao mesmo tempo superam suas condições unicamente naturais por meio do trabalho concreto. Isso os diferencia dos outros animais cujas atividades estão estruturalmente vinculadas a sua existência imediata, biológica, natural (MARX, 1983).

Mas qual o problema? A categoria central à sociabilidade humana, decisiva para a sobrevivência e a evolução da espécie, se objetiva como abstrata-estranhada na sociedade do capital (MARX, 1983; 2004), ou seja, o trabalho prioritariamente não mais se constitui como realização humana transformando-se em trabalho coisificado, reificado, subjugado ao capital, configurando-se como uma forma histórica de trabalho. Como se sabe, esse tipo de trabalho separa a força de trabalho, os instrumentos de produção (máquinas, ferramentas, etc.) e o produto do trabalho (como mercadoria). Coisifica as relações humanas, transforma a força de trabalho em mercadoria específica, institui o fetiche da mercadoria, subsumindo ${ }^{9}$

\footnotetext{
8 É preciso destacar que o fato desse processo, hoje, ser comandado pelo capital, tem levado a própria natureza a graves níveis de esgotamento (MÉSZÁROS, 2002).

9 Isso é, não apenas submetendo a força de trabalho ao capital, mas, simultaneamente, reafirmado que um não se realiza sem o outro.
}

Argum., Vitória, v. 10, n. 2, p. 56-69, maio/ago. 2018. 
as potencialidades emancipatórias contidas na categoria trabalho (útil-concreta) à valorização do capital (MARX, 2004).

O capitalista, mediante a compra da força de trabalho, incorporou o próprio trabalho, como fermento vivo, aos elementos mortos constitutivos do produto, que lhe pertencem igualmente. Do seu ponto de vista, o processo de trabalho é apenas o consumo da mercadoria, força de trabalho por ele comprada, que só pode, no entanto, consumir ao acrescentar-lhe meios de produção (MARX, 1983, p. 154).

Essa constatação de Marx, diferentemente da economia política clássica inglesa, sustenta a tese de que o trabalho concreto-útil precisa ser liberado como componente intrínseco à emancipação humana, conquistada coletiva e socialmente e expressa individualmente, obtido com “[...] forces propres (forças próprias) como forças sociais” (MARX, 2009, p. 71) ${ }^{10}$. A continuidade e o aprofundamento de seus estudos no campo da economia política (entendida como produção e reprodução da existência humana a partir de condições históricas dadas), sempre orientado pela perspectiva da totalidade, continuam em $A$ miséria da filosofia (MARX, 1987), são densamente aprofundadas nos Grundrisse (MARX, 2011) e nos Manuscritos Econômicos de 1861-1863 (MARX, 2010), objetivando-se com maior densidade em $O$ Capital, na totalidade dos seus três livros. A apreensão marxiana é saturada por uma análise que perquire a trama da sociedade do capital, sua reprodução em escala ampliada, como processo produtivo contínuo que unifica sem identificar momentos necessários à acumulação: capital monetário, capital mercadoria, capital produtivo e capital industrial; que cria e recria valor como acumulação ampliada; expropria a força de trabalho; e gera mais-valia (repartida em várias partes e reconvertida de diferentes formas), como momentos de um processo geral de produção e circulação que se metamorfoseiam, alterando a composição orgânica do capital (MARX, 1984a), ou seja, a relação dinâmica entre capital constante e variável (tendencialmente em favor do primeiro).

Enquanto formas, maneiras de existência específicas, distintas, que correspondem a funções específicas do capital industrial, o capital monetário só pode executar funções monetárias, o capital-mercadoria apenas funções mercantis; a diferença entre eles é somente a que existe entre dinheiro e mercadoria. Da mesma forma o capital industrial, em sua forma capital produtivo, só pode ser constituído pelos mesmos elementos, como qualquer outro processo de trabalho formador de produtos: por um lado, condições objetivas de trabalho (meios de produção); por outro, força de trabalho que se ocupa produtivamente (tendo em vista um fim) (MARX, 1984b, p. 6o)

É por isso que a forma como a categoria trabalho vem se objetivando e se particularizando no capitalismo, subsumindo sua dimensão útil-concreta, carece de crítica permanente, radical, material, capaz de liberá-la como força humanizadora dos seres sociais, liberdade fundamental para estimular o desenvolvimento de sua potência humano-genérica. Não se trata, aqui, de uma crítica abstrata, centrada em um puro desejo-intenção, mas de uma crítica objetiva, real, vinculada a aspectos que sustentam objetivamente a reprodução ampliada do capital. É nesse sentido que a crítica radical de Marx à teoria valor-trabalho

\footnotetext{
${ }^{10}$ Essa tendência de crítica à ordem do capital se aprofundou e se objetivou gradualmente na obra marxiana desde seus estudos de juventude, claramente expostos (e coerente com o conjunto de sua teoria social) em $A$ questão judaica (MARX, 2009), em Crítica à filosofia de Hegel - introdução (MARX, 2005b) e nos Manuscritos Econômico-Filosóficos de 1844 (MARX, 2004).
}

Argum., Vitória, v. 10, n. 2, p. 56-69, maio/ago. 2018. 
clássica, sobretudo por meio da explicação dos mecanismos de extração de mais-valia, do trabalho como fonte original do valor nas diferentes fases do capitalismo, adquire materialidade efetiva como possibilidade de ruptura revolucionária. Trata-se, portanto, de uma sociedade que possui limites de sustentabilidade efetivos, uma vez que põe e repõe, continuadamente, como condição para sua reprodução ampliada, contradições insolúveis sobre suas fronteiras.

Somente neste contexto, assentado sob tais bases, que a categoria revolução adquire concretude como componente inseparável da teoria social de Marx. Lukács (2012) destaca que o socialismo (com primeira etapa do comunismo) se apresenta como desdobramento necessário da dialética do ser social, de uma autoexplicação da economia real, seus pressupostos como resultado da luta de classes (sempre como possibilidade histórica objetiva). Não se impõe, aqui, uma revolução como um ato utópico, abnegado, idealista, desconectado da realidade. Ao contrário, o sucesso da revolução depende de um conjunto de elementos capazes de articular, simultaneamente, três aspectos: a) o desenvolvimento das forças produtivas; b) a luta de classes potenciada por sujeitos históricos na sua historicidade; c) a construção de alternativas factíveis, reais, sempre transitórias, possíveis, seguramente imperfeitas, mediadas por casualidades históricas, mas claramente e intencionalmente perseguidas. Mais do que isso, a revolução não se imporá localmente, isoladamente, mas mundialmente, sobretudo nos espaços em que a sociedade do capital se desenvolveu mais plenamente. Isto não significa descartar processos de resistência que brotam em regiões do globo marcadas pelo capitalismo dependente (seguramente importantes), mas afirmar que esses países não alcançarão a revolução isoladamente, a partir deles próprios ou mesmo de um bloco de países. O colapso do capital deve conter características mundiais e estruturais. Destacam Marx e Engels no Manifesto do Partido Comunista:

\begin{abstract}
As proposições teóricas dos comunistas não se baseiam, de modo nenhum, em ideias ou em princípios inventados ou descobertos por este ou aquele reformador do mundo. São apenas expressões gerais de relações efetivas de uma luta de classes que existe, de um movimento histórico que se processa diante de nossos olhos. [...] a moderna propriedade privada burguesa é a expressão última e mais acabada da produção e da apropriação baseada em antagonismos de classe, na exploração de umas pelas outras. Neste sentido, os comunistas podem condensar a sua teoria numa expressão única: supressão da propriedade privada. [...] (MARX; ENGELS, 1998, p. 21)
\end{abstract}

É necessário dizer, então, que o socialismo e o comunismo não representam "o fim da histórica", e que a economia (como produção e reprodução do ser social) continuará sendo importante para a satisfação de necessidades humanas, para a vida humana (como base ontológica permanente). A diferença fundamental entre capitalismo e socialismo está no fato de que o primeiro cria, espontaneamente, uma produção social (ainda que isso não se imponha tranquilamente), enquanto o segundo transforma essa espontaneidade em regulação consciente (LUKÁCS, 2012). Certamente, aqui, o Estado terá uma função importante na regulação social, como "[...] ditadura revolucionária do proletariado" (MARX, apud NETTO, 2012, p. 440 $)^{11}$. A polêmica palavra ditadura, amplamente explorada pela

${ }^{11}$ Naturalmente que a afirmação marxiana sobre o protagonismo do proletariado se sustenta nas condições objetivas da segunda metade do século XIX. Nossa apreensão é que a participação do proletariado urbano e industrial em processos revolucionários continua atual, bem como a importância dos partidos

Argum., Vitória, v. 10, n. 2, p. 56-69, maio/ago. 2018. 
direita liberal, neoliberal e ultraliberal (na sua diversidade), como uma ação antidemocrática (seguramente não afinada com a democracia burguesa), criticada por segmentos reformistas de diferentes espécies ou reduzida a uma pura imposição da burocracia partidária como um exclusivo assalto ao poder (inspirado na vanguarda stalinista), deve ser entendida como imposição de interesses hegemônicos de classe em uma fase transitória e revolucionária, como transição socialista que eduque e construa um novo Homem (homens e mulheres como gêneros humanos), no sentido amplo, com valores centrados na igualdade social que não é sinônimo de identidade social, mas de igualdade na diversidade, igualdade nas diferenças ou, para Marx (apud NETTO, 2012), "[...] De cada qual, segundo sua capacidade; a cada qual, segundo suas necessidades. [...]” (MARX apud NETTO, 2012, p. 432).

Não há, aqui, nenhum tipo de ilusão. Todos os processos revolucionários passaram por transições tensas em que os grupos hegemônicos objetivamente se impuseram diante dos interesses dos segmentos sociais defensores de sociedades decadentes. Dessa forma se impôs, por exemplo, a burguesia como classe hegemônica no final do século XVIII. A transição socialista e a ditadura do proletariado se imporiam não como um simples assalto ao poder, mas se objetivariam com ações políticas de Homens concretos a partir de condições objetivas concretas, reais, contidas nas próprias contradições internas da ordem burguesa, desenvolvendo projetos alternativos a essa sociedade orientados intencionalmente pela igualdade social (nesse sentido, genuinamente democrático). Portanto, para Marx, o socialismo significa a continuidade da história, o fim da pré-história da humanidade, ou seja, a histórica continua a partir de novas bases sociais centrada no controle consciente da produção social, como um movimento material-objetivo marcado por rupturas com continuidades, unidade do diverso, reposição de novas contradições. Destaca Marx no livro III de O Capital:

Nesse terreno, a liberdade só pode consistir em que o homem social, os produtores associados, regulem racionalmente esse seu metabolismo com a natureza, trazendoo para seu controle comunitário, em vez de serem dominados por ele como se fora uma força cega; que o façam com o mínimo emprego de forças e sob as condições mais dignas e adequadas à sua natureza humana (MARX, apud LUKÁCS, 2012, p. 416).

Como tudo em Marx (na sua teoria social) não existem receitas, ainda que existam tendências possíveis tecidas na vida real de seres sociais em luta. Apontar possibilidades não significa, em absoluto, realizá-las. A solução, nesse sentido, está na práxis social, no pensarfazer concreto, histórico, historiado, orientado pelo ponto de vista da totalidade e contaminado por uma explícita não neutralidade em favor daqueles que vivem da venda da força de trabalho ainda que eles próprios, em tempos de hegemonia do capital, não reproduzam, conscientemente, a consciência de sua classe social ${ }^{12}$.

revolucionários e dos sindicatos, ainda que seja necessário destacar, hoje, uma brutal redução do proletariado fabril e a diversificação objetiva da classe trabalhadora.

${ }_{12}$ Esse cenário, seguramente, insere dados reais que não podem ser subestimados no debate sobre as atuais possibilidades revolucionárias e quais seriam seus protagonistas no início do século XXI. Todavia, esse "esterco de contradições" não descarta a categoria revolução como possibilidade real, tampouco a importância da luta de classes e do papel exercido pela heterogênea classe trabalhadora na fase monopolistafinanceira do capital.

Argum., Vitória, v. 10, n. 2, p. 56-69, maio/ago. 2018. 


\section{OBSERVAÇÕES FINAIS}

O legado de Marx às esquerdas revolucionárias supõe a valorização de sua teoria social a partir de uma categoria ontológica e gnosiológica essencial: a totalidade. Mas o desafio em absoluto é teórico e prático, mas teórico-prático, como práxis social que persegue o movimento do real para reproduzi-lo no pensamento o mais corretamente possível, como concreto-pensado, tensionando na direção da 11 ${ }^{\mathrm{a}}$. Tese sobre Feuerbach: mudar o mundo crítica e materialmente a partir das condições efetivamente dadas. Qualquer perda dessa referência como base, significará uma recaída idealista e, claro, uma destruição da razão ontológica (em termos lukácsianos).

A atualidade da teoria social de Marx para a análise do atual momento histórico não se sustenta em um protocolo de intenções. Os mesmos mecanismos que recolocam as condições para a manutenção ampliada do capital (hoje na sua fase madura, monopolista, dominada por sua fração financeira e orientada pelo padrão de acumulação toyotista dentro das condições dependentes da América Latina (MARINI, 2008; FERNANDES 2009)), recolocam os próprios mecanismos para sua superação, reafirmando a desigualdade social estrutural e os inumeráveis dilemas indissolúveis contidos nessa sociedade. Portanto, reafirmam as possibilidades para sua superação contando com os protestos do proletariado clássico e do conjunto dos trabalhadores desapropriados que vivem, diversamente, hoje, da venda da sua força de trabalho. Reconstruir mentalmente as atuais determinações históricas, a realidade objetivamente posta, é procedimento necessário para fomentar ações concretas de resistência. Portanto, a revolução não é uma abstração, mas uma possiblidade histórica real cuja base se sustenta no próprio capital e em suas crises. Este, por sua vez, põe e repõe, historicamente, as múltiplas consequências da apropriação privada da produção e reprodução social explicada pela Lei Geral da Acumulação Capitalista (MARX, 1984a), amplamente argumentada por Marx no conjunto da sua obra e a partir de sua vivência e militância junto à classe operária inglesa. Seguramente as particularidades atuais e suas diversas mediações não são as mesmas comparadas com o tempo histórico de Marx, mas os pressupostos fundantes revelados e tratados por ele são absolutamente necessários e essenciais para que as esquerdas atuem contra a barbárie claramente posta na vida social. Dessa forma, a sociedade do capital, suas próprias contradições como ordem social e a luta de classes nela contida, oferecem os elementos objetivos para sua superação material. $\mathrm{O}$ método em Marx nos oferece as condições metodológicas para atualizar coerentemente sua teoria social, sem recaídas idealistas de qualquer espécie ou reformismos conservadores travestidos de "democráticos". Esse choque, radicalmente marxiano e seguramente antidogmático, é decisivo para a genuína resistência de esquerda e para a sobrevivência dos marxismos, como crítica e autocrítica.

Sendo assim, a reconstrução mental do materialmente existente como unidade-diversa entre pensamento e realidade, é traço essencial - embora insuficiente - à práxis social e a toda atividade necessária à crítica radical. $O$ que existe aqui, claro, é a superação do imediatamente posto como dinâmica que se explica por si, sem conexões explicativas (mediações), sem determinações de classe objetivamente existentes, como ações localizadas, desconexas, viabilizadas por sujeitos individuais e ou sociais que não seguem referências históricas, mas casuais e pontuais, como uma infinidade de fragmentos sociais desconectados entre si. Para estes, a categoria da totalidade inexiste ou é inalcançável,

Argum., Vitória, v. 10, n. 2, p. 56-69, maio/ago. 2018. 
movendo-se entre formas de idealismo/logicismo sejam eles subjetivos ou objetivos, irracionalistas ou racionalistas. Mas a dialética em Marx, sua noção de totalidade-dinâmica materialmente posta, mutável, repleta de conflitos e contradições, que não reduz o real ao racionalmente pensado, também supera as noções que tendem a articular com maior dinamismo o todo e as partes como estímulo ao equilíbrio sistêmico sustentado em subsistemas. Para estes, a realidade dada é dinâmica, ajustável e essencialmente eterna. Ou seja, se alternam e se modernizam as formas para gerenciar as tensões realmente existentes, sem que sejam afetadas suas leis essenciais, o "curso natural" do sistema.

No campo particular das profissões, entre elas o Serviço Social, o debate com Marx e com sua tradição é essencial para o processo de desvelamento da trama contida na sociabilidade burguesa que determina as condições objetivas por onde os profissionais e as próprias profissões se constituem. Todavia, todo cuidado é pouco para não superestimar essa dimensão ou, ao contrário, condená-la ao puro imobilismo ${ }^{13}$. Profissões se inscrevem objetivamente a partir de condições seguramente restritas, inseparáveis, no caso do Serviço Social, das políticas que fazem a gestão da questão social e de suas inúmeras refrações (NETTO, 1996). Os profissionais que aqui atuam não escapam destas determinações (inscritas na ordem social que as criou), muito embora seja absolutamente essencial que se insiram neste espaço contraditório estimulados pela crítica radical que forceja as fronteiras das profissões e tensiona seu alcance. O exato sentido da explicação desta complexidade, repleta de armadilhas e jamais isenta de erros, permite formar profissionais críticos, não idealistas, teoricamente sólidos e sujeitos-profissionais possíveis, isto é, conhecedores ainda que relativamente - dos limites objetivos a eles impostos e às suas profissões, mas inquietos, criativos e fomentadores de ações de resistência que extrapolam o campo restrito de sua atuação profissional. Claro que a referência aqui não é prioritariamente a profissão, mas a emancipação humana (MARX, 2009). O segredo, todavia, está em não atribuir às profissões o que elas objetivamente são incapazes de realizarem, embora seja absolutamente necessário e legítimo sintonizá-las com níveis crescentes e emancipação social reconstruindo as mediações necessárias para tal (SILVA, 2013).

Sábias são as palavras de Lenin sobre os equívocos cometidos quando se adota o caminho seguro das receitas prontas para construir o futuro (LUKÁCS, 2012):

Nem sequer a Marx veio à mente escrever uma só palavra sobre essa questão se ele morreu sem deixar nenhuma citação precisa ou indicações irrefutáveis. Por isso, devemos nos virar por nós mesmos (LUKÁCS, 2012, p. 422).

\section{REFERÊNCIAS}

FERNANDES, Florestan. Capitalismo dependente e classes sociais na América Latina. São Paulo: Global, 2009.

\footnotetext{
${ }^{13}$ Nesse nível diversas interpretações se apresentam: desde aplicações militantes centradas em ações ordenadas em nome da defesa - acrítica e descontextualizada - dos direitos, até a completa desqualificação da profissão e dos profissionais. Ambas alternativas reeditam, nas condições atuais, formas de messianismo e de fatalismo já tratadas por Marilda Iamamoto (1994; 2007).
}

Argum., Vitória, v. 10, n. 2, p. 56-69, maio/ago. 2018. 
IAMAMOTO, Marilda Villela. Renovação e conservadorismo no serviço social: ensaios críticos. São Paulo: Cortez: Celats, 1994.

IAMAMOTO, Marilda Villela. Serviço social em tempo de capital fetiche: capital financeiro, trabalho e questão social. São Paulo: Cortez, 2007.

LENIN, V. I. O imperialismo: fase superior do capitalismo. São Paulo: Centauro, 2008.

LUKÁCS, György. Para uma ontologia do Ser Social II. São Paulo: Boitempo, 2013.

LUKÁCS, György. Para uma ontologia do ser social I. São Paulo: Boitempo, 2012.

LUKÁCS, György. Prolegômenos para uma ontologia do ser social. Tradução de Carlos Nelson Coutinho. São Paulo: Boitempo, 2010.

LUKÁCS, György. LUKÁCS. Organizado por José Paulo Netto. São Paulo: Ática, 1981. (Grandes cientistas sociais).

MARINI, Ruy Mauro. América Latina, dependencia y globalización. Bogotá: CLACSO y Siglo del Hombre, 2008.

MARX, Karl. Grundrisse: manuscritos econômicos de 1857-1858. São Paulo: Boitempo, 2011.

MARX, Karl. Para a crítica da economia política: manuscrito de 1861-1863: cadernos I a V: Terceiro capítulo: O capital em geral. Belo Horizonte: Autêntica, 2010.

MARX, Karl. Para a questão judaica. São Paulo: Expressão Popular, 2009.

MARX, Karl. Critica da filosofia do direito de Hegel. São Paulo: Boitempo, 2005a.

MARX, Karl. Crítica da filosofia do direito de Hegel: Introdução. In: MARX, Karl. Critica da filosofia do direito de Hegel. São Paulo: Boitempo, 2005b. p. 145-56.

MARX, Karl. Manuscritos econômico-filosóficos. São Paulo: Boitempo, 2004.

MARX, Karl. O método da economia política. In: FERNANDES, Florestan (Org). Marx e Engels: história. 3. ed. São Paulo: Ática, 1989. (Textos originais de Marx e Engels).

MARX, Karl. Miseria de la filosofía: respuestas a la Filosofía de la miseria de Proudhon. México: Siglo XXI Ediciones, 1987.

MARX, Karl. O capital: crítica da Economia Política. São Paulo: Abril Cultural, 1983. v.1, tomo 1.

MARX, Karl. O capital: crítica da Economia Política. São Paulo: Abril Cultural, 1984a. v.1, tomo 2.

MARX, Karl. O capital: crítica da Economia Política. São Paulo: Abril Cultural, 1984b. v.2. 
MARX, Karl. O capital: crítica da economia política. São Paulo: Abril Cultural, 1984c. v.3, tomo 1.

MARX, Karl. O capital: crítica da economia política. São Paulo: Abril Cultural, 1985. v.3, tomo 2.

MARX, Karl; ENGELS, Friedrich. A ideologia alemã. São Paulo: Boitempo, 2007.

MARX, Karl; ENGELS, Friedrich. Manifesto do Partido Comunista - prólogo de José Paulo Netto. São Paulo: Cortez, 1998.

MÉSZÁROS, István. Para além do capital. São Paulo: Boitempo, 2002.

NETTO, José Paulo (Org.). O leitor de Marx. Rio de Janeiro: Civilização Brasileira, 2012. (Textos originais de Marx).

NETTO, José Paulo. Transformações societárias e Serviço Social: notas para uma análise prospectiva da profissão no Brasil. Serviço Social \& Sociedade, São Paulo: Cortez, n. 5o, p. 87-132, abr. 1996.

SILVA, José Fernando S. da. Serviço social: resistência e emancipação?. São Paulo: Cortez, 2013.

\footnotetext{
José Fernando Siqueira da SILVA

Assistente Social. Doutor em Serviço Social pela Pontifícia Universidade Católica de São Paulo. Livre-docente em Serviço Social pela UNESP. Docente do Programa de Pós-Graduação em Serviço Social e Políticas Sociais da Universidade Federal de São Paulo (UNIFESP). Professor do Departamento de Serviço Social da UNESP-Franca (graduação). Bolsista produtividade em pesquisa do CNPq desde março de 2009 e coordenador do projeto "Serviço Social e Tendências Teóricas Atuais", processo FAPESP 2017/14497-5. Líder do Grupo de Estudos Teoria Social de Marx e Serviço Social e orientador do Centro de Planejamento e Extensão Universitária em Serviço Social (CPEUSS).
} 